Els Goulmy

Authors address

Els Goulmy

Department of Immunohematology and Blood

Bank

Leiden University Hospital

P O Box 9600

2300 RC Leiden

The Netherlands

Fax 31-71-5216751

e-mail ihbsecr@euronet nl

Acknowledgements

I would like to thank Els Blokland and Jos Pool for their contributions over the years to the original work of the laboratory I am indebted to Marleen de Bueger, Ceclle van Els, Joke den Haan, Dick van der Harst, Linda Jiem and Ellen van Lochem for their essential scientıfic contributions, Isabelle Miconnet, Tuna Mutis and Ellen Schrama for fruıtful discussions, and Roel Willemze, Fred Falkenburg and Jaak Vossen whose patients were mcluded in the mvestıgations I am grateful to Jon van Rood, who performed the last minute critıcal reading, and Ingrid Curiel for the superb typing I thank Drs Roosnek, Simmons and Taurog for providing the results of their work before publicatison. Thes work was supported in part by grants from the Dutch Organısation for Scientific Resear.h (NWO), the Dutch Cancer foundation, the J A Cohen Institute for Radiopathology Rad'iation Protection (IRS), and the Macropa Fuundation, as well as a European Biotech EC grant

Immunological Reviews 1997

Vol $157 \quad 125-140$

Printed in Denmork All nghts reserved

Copynight (C) Munksgaard 1997

Immunological Reviews

ISSN 0105-2896

\title{
Human minor histocompatibility antigens: new concepts for marrow transplantation and adoptive immunotherapy
}

\begin{abstract}
Summary. Bone marrow transplantation (BMT) is the present treatment for hematological malıgnancies 'Two major drawbacks of allogeneic BMT are graft-versus-host disease (GVHD) and leukemia relapse The use of HLA-matched siblings as marrow donors results in the best transplant outcome Nonetheless, the results of clnncal BMT reveal that the selection of MHC-Identical donors' bone marrow (BM) is no guarantee for avolding GVHD or ensuring disease-free survival even when donor and recipient are closely related It is believed that non-MHC-encoded so-called mmor histocompatıbility antigens ( $\mathrm{mHag}$ ) are involved in both graft-versus-host and graft-versus-leukemia activities The recent new insights into the chemical nature of mHag not only reveal their physiological function but, more importantly, provide insights into their role in BMT Together with the information on the human mHag genetics and tissue distribution gathered in the past, we may now apply thus knowledge to the benefit of human BMT Directly relevant is the utility of mHag molecular typing for diagnostics in BM donor selection Most promising is the use of mHagspecific cytotoxıc $T$ cells for adoptıve ummunotherapy of leukemıa
\end{abstract}

\section{Introduction}

Minor histocompatibility antigens (mHag) are products of genetic loci responsible for graft rejection As the MHC encoded major $\mathrm{H}$ systems, the minor $\mathrm{H}$ antigens have important biological functions besides their role in organ and bone marrow transplantation (BMT) Their latter characterıstıc, however, was first disclosed Both types of transplantation ant1gens were described by Snell (1) and dissevered from one another on the basis of their respective power in murme tumor graft rejection models (2) Skın-grafting experiments in the mouse demonstrated the presence of a large number of histocompatibility antıgens coded for by multuple locı scattered all over the genome They showed distmgurshable patterns in elicitmng allogeneıc reaction, skın graftıng over a multıple minor $\mathrm{H}$ barrier demonstrated a graft rejection time comparable to those that duffered only at $\mathrm{H}-2$ (2-4)

In human transplantation, donors and recipients are routunely screened for identification of the major $\mathrm{H}$ system, therefore, graft-versus-host disease (GVHD) and rejectıon may be 
Table 1. MHC class I restriction of $\mathrm{H}-\mathrm{Y}$-specific cytotoxic and proliferative $\mathrm{T}$-cell responses

\begin{tabular}{|c|c|c|c|}
\hline UPN & PBLs derived ${ }^{b}$ & CD8 CTL & CD4 CTL \& Th \\
\hline \multirow[t]{2}{*}{1} & Post BMT & HLAAZHY & $\mathrm{HLA} A 2 \mathrm{HY}$ \\
\hline & & & HLA B $60 \mathrm{HY}$ \\
\hline 2 & After muluple transfusions & HLA A2 HY & \\
\hline \multirow[t]{2}{*}{3} & After multiple transfusions & HLA AZHY & \\
\hline & & HLA B7 HY & \\
\hline 4 & After multiple transfusions & HLA A1 HY & \\
\hline 5 & Post renal transplant & HLA B7 HY & \\
\hline
\end{tabular}

unique patient number all patients are female

'peripheral blood lymphocytes

caused by the disparity of the products of the minor H systems, i e histocompatıbility antigens other than those coded for by the MHC

The description by Zinkernagel \& Doherty (5) of the classical immunological phenomenon of the MHC-restricted rec ognition of viral antigens by $T$ cells appeared also to apply to the recognition of non-MHC alloantugens In the seventies, murine $(6,7)$ and human $(8,9)$ mHag were defined in vitro by MHC-restricted $T$ cells

In man, mHag studies have predominantly been performed in the HLA-ıdentical BMT setting The efforts of several invest1gators have led to the identıfication of a relatıvely small number of mHag Both cytotoxic T cells (CTLs) and T-helper (Th) cells recognizing mHag in a classical MHC-restricted fashıon were described MHC molecules serve as templates (10) for peptides derived from intracellularly processed protems $(11,12)$ This knowledge was essential for the prediction that mHag are naturally processed fragments of intracellılar protenns that associate with MHC molecules $(13,14)$ Indeed, this supposition was recently verified both for murme (15) and human mHag (16)

This review summarizes our current knowledge of the impact of mHag on the outcome of BMT and discusses the putative clinıcal applicabilities now that biochemical identrfication of mHag is possible

\section{The male-specific mHag $\mathrm{H}-\mathrm{Y}$ - cellular recognition}

The involvement of $\mathrm{H}-\mathrm{Y}$ (at that time called $\mathrm{Y}$-factor) $\mathrm{m}$ homograft rejection had been postulated by Eichwald \& Shmser (17) in 1955 The term H-Y antigen was introduced by Billingham \& Silvers (18) since the Y-factor is a transplantation ant1gen, determined by a histocompatibility gene, comparable in all respects to the antigens responsible for homograft rejectıon

In vitro immune response agannst the human-male specific histocompatıbility antıgen $\mathrm{H}-\mathrm{Y}$ was detected in a multı-trans- fused female aplastic anemia patient She receıved, after ant1thymocyte globulm (ATG) pretreatment, a bone marrow (BM) graft, donated by her HLA-genotypically identical male sibling In vitro analysis of the post-transplant peripheral blood lymphocytes (PBLs) of the female patient (HLA phenotype HLA-A2, $\mathrm{A} 2, \mathrm{~B} 44, \mathrm{~B} 60$, Cw3, Cw5, DR4, DRw6) showed unambiguously strong CTL responses specific for male HLA-A2-positive target cells $(8,9)$ Whether the H-Y-specific CTLs actually mediated the allograft rejection, we do not know It must be remarked, however, that most probably the female patıent, who was suffering from severe aplastic anemia, had been sensitızed to the $\mathrm{H}-\mathrm{Y}$ antigen prior to transplantation through multiple blood transfusions and pregnancies Interestingly, the antı- $\mathrm{H}-\mathrm{Y}$ response in the latter patient appeared broader than the HLA-A2-restricted CD8 CTL clones We isolated two CD4 cytotoxic and proliferatıve $\mathrm{H}-\mathrm{Y}$-specific clones one restricted via HLA-A2 and the other one recognized an H-Y T-cell epitope in association with HLA-B60 (Table 1) (19)

Although in our first case we could not formally prove that the H-Y-specific CTLs actually mediated the rejection of the male BM allograft, some years ago we were confronted with a case with a fatal outcome in which ant1-H-Y CTLs were most probably mannly responsıble for BM graft fallure It concerned a multı-transfused female patıent suffermng from myelodysplasia after treatment for Hodgkin's disease In vitro analysis prior to BMT demonstrated the presence of HLA-A1-restricted antiH-Y CTLs (Table 1 UPN 4) Since the father appeared to be the only HLA-compatible related donor, he was the obvious choice (despite the presence of the patient's pretransplant antı- $\mathrm{H}-\mathrm{Y}$ CTLs) Notwithstanding intensive pretransplant immunosuppressive treatment, there was no recovery of the BM hematopoietuc function (20) In view of the latter case, expression of mHag on hematoporetic stem cells (HPCs) might be relevant in presensitized patients receiving an mHag-positive T-celldepleted marrow graft For that purpose, the expression of the male-specific antigen $\mathrm{H}-\mathrm{Y}$ was studied for its expression on HPCs It became clear that, indeed, $\mathrm{H}$-Y is expressed on CFUGEMM, CFU-GM and BFU-E (21) The assumption that H-Y sensitization can readily occur following blood transfusion and organ transplantation is based on our subsequent observations As shown in Table 1, PBLs derived from three additional cases showed, after in vitro restimulation with HLA-ıdentical male cells, exactly the same phenomenon, namely HLA-restricted $(-A 1,-A 2$ and/or -B7) ant1-H-Y CTI activity In one patient (Table 1 UPN 5), the H-Y-specific HLA-B7-restricted cytotoxic1ty was detected shortly after a kidney donated by an HLA-ıdentıcal male sibling acutely rejected (unpublished observation) In curcumstances similar to ours, other investigators have also 
Table 2. Identification of human mHag

\begin{tabular}{|c|c|c|c|c|}
\hline $\begin{array}{l}\text { Restriction } \\
\text { molecule }\end{array}$ & $\mathrm{mH}$-lag & $\begin{array}{l}\text { peptide } \\
\text { (amıno acids) }\end{array}$ & $\begin{array}{l}\text { Chromosomal } \\
\text { location }\end{array}$ & orign funct on \\
\hline HLA B7 & $H Y$ & SPSVDKARAEL (11AA) & Y & SMCY presently unknown \\
\hline HLA A2 1 & HY & FIDSYICQV (9AA) & Y & SMCY \\
\hline HLA A2 १ & $\mathrm{HA} 2$ & YIGEVLVSV (9 AA) & $?$ & $\begin{array}{l}\text { non filamentous class i myosina } \\
\text { involved in cell locomotion and } \\
\text { organelle transport }\end{array}$ \\
\hline
\end{tabular}

apostulated origin based on homology of 7 out of 9 AA

described the presence of HLA-restricted H-Y-directed cytotoxIcity (22-24)

To elaborate on the function of the antigen-presenting molecule as well as on the antigen recognized, in vitro studies were carried out with HLA-A2 "varıant" molecules and abnormal chromosomal sex patterns, respectively The analysis of the epitopes on the HLA-A2 molecule required for cellular recogmition of the $\mathrm{H}-\mathrm{Y}$ antigen led to the observations that alloimmune HLA-A2-specific CTLs $(25,26)$ as well as HLA-A2restricted $\mathrm{H}-\mathrm{Y}$-specific CTLs (27) can distınguish between different HLA-A2 molecules Combined investigations (resulting from a collaborative effort) of the HIA-A2-subtype molecules at the functional level demonstrated that amino acid changes at position 43 and in the residues 145-157 (1 e cellularly defined subtypes HLA-A2 2 and HLA-A2 3) lead to the loss of epitope(s) necessary for associative recognition of the $\mathrm{H}-\mathrm{Y}$ antigen by HIA-A2-restricted CTLs $(27,28)$ Interestingly, a single amino acid change from phenylalanine to tyrosine at position 9 in the heavy chain of the HLA-A2 molecule ( 1 e cellularly defined subtype HLA-A2 4) did not affect the recognutıon of H-Y by HLA-A2-restricted CTLs (27) These analyses, carried out well before the crystal structure of HIA-A2 became avallable, led us to postulate crucıal MHC/peptıde-binding sites as well as to distinguish harmful from irrelevant amıno acid changes in the HLA-A 2 molecule The identification of the HLA-A2-binding H-Y peptide (see below) together with the avalability of the $\mathrm{HI} A-\mathrm{A} 2$ crystal structure ensure that the postulated MHC/peprıde--bindıng sites can now be verıfied

The function and the chromosomal location of the histocompatıbility antigen $\mathrm{H}-\mathrm{Y}$ were also sought We studied lymphocytes from individuals with a discrepancy between the karyotype and phenotypic sex Besides a clear positive reaction with the cells of an XY female, the H-Y-specific CTLs showed no reactıvity when analyzed agamst XX males (29) Exammation of sex-reversed humans by combined analyses of different sets of Y-DNA probes and H-Y-specific CTIs revealed that the gene for H-Y maps to the long arm or centromerıc region of the human $Y$ chromosome (30), thereby separating the H-Y gene from the testis-determining factor (TDF) locus In add1tıonal studies, it could be shown that a loss of spermatogenesis did not correlate with absence of the mHag H-Y CTI recognition, thereby separating the azoospermia factor (AZF) locus from the locus coding for the mHag H-Y (31) Extensive dele tıon-mapping studıes using specıfic DNA markers revealed that the $\mathrm{H}$ - $\mathrm{Y}$ antigen, as determined by our HLA restricted $\mathrm{H}$ Y-spe cific CTL clones, maps to a portion of deletion interval 6 on the long arm of the human Y chromosome $(32,33)$

\section{The male-specific mHag $\mathrm{H}-\mathrm{Y}$ - bıochemıcal Identification}

Being among the H-Y "searchers" since 1976, we were challenged to identify the human mHag H-Y The mHag-specific T-cell clones have been used for the biochemucal identification of the H-Y peptides The biochemical isolation procedure, i $\mathrm{e}$ affinity chromatography combined with microcapillary reversed-phase high-performance liquid chromatography (HPLC) coupled with electrospray ionization mass spectrometry (34), was successfully used for the identufication of the mHag peptides The H-Y antigen presented by the HLA-B7 molecule was the first one described (35) (Table 2) The HLA-B7-restricted H-Y T-cell epitope was identıfied as an 11 residue peptide derived from the human homologue of the selected mouse cDNA on the Y (Smcy) gene (see below) encoded on the $Y$ chromosome (35)

The genetic mapping of the mouse $\mathrm{Y}$ chromosome has suggested between two and five distınct locı encoding $\mathrm{H}-\mathrm{Y}$ antigens (36) However, a murme $H-Y$ epitope restricted by $\mathrm{H}-2 \mathrm{~K}^{\mathrm{k}}$ has also been shown to be derved from the murme Smcy protein (37) The demonstration that two H-Y epitopes from elther mouse or human are derived from the same protein makes SMCY the prime target in searching for other H-Y epitopes Therefore, we set out to identify the H-Y T-cell epitope presented by the HLA-A2 molecule Indeed, the H-Y peptıde recognuzed by our HLA-A2-restricted T-cell clones also originates from the SMCY proteun (Table 2) (38) Two HLA-A2restricted $\mathrm{H}$-Y-specific $\mathrm{T}$-cell clones were used in this study 


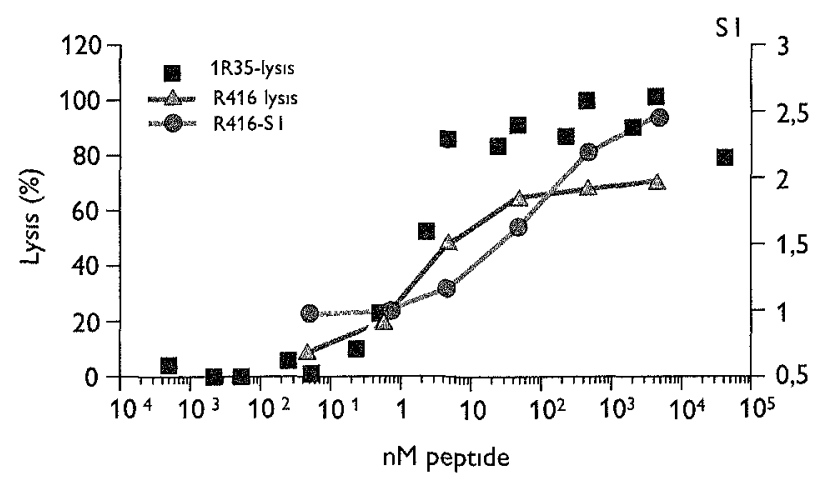

Frg. 1. Cytotoxic and proliferative HLA-A2 H-Y peptide-specific responses. For both responses, 10,000 responder cells and 50,000 female stimulator/target cells pulsed with various amounts of $\mathrm{H} Y$ peptide are used Effector/target ratıos are 111 and 181 for IR35 and R416, respectively

S I Stimulation Index (measurement of proliferation)

(Table 1) a CD8 CTL clone (designated as IR35) and a CD4 cytotoxuc and prohferative T-cell clone (designated as R416) (19), IR35 and R416 were derived from the same individual (Table 1 UPN1) Both clones recognize the 9-residue peptide FIDSYICQV (Fig 1) with significant cytolytic and proliferatıve responses Interestingly, post-translation modification of this H-Y epitope significantly altered the recognition, especially of the CD4 H-Y T-cell clone The latter clone clearly preferred the cysteunylated form of the $\mathrm{H}$-Y peptıde, whereas the CD8 $\mathrm{H}-\mathrm{Y}$ T-cell clone recognized both peptıde forms equally well (38)

The importance of the SMCY protein as a major source of $\mathrm{H}-\mathrm{Y}$ determunants was recently further underlined Prelımmary results from a collaboratıve study (Roosnek et al manuscript m preparation) showed HLA-A2-restricted $H$ - $Y$ reactivity against one dominant $\mathrm{H}$-Y epitope 15 male-specific CTI clones isolated from 3 individuals recognized the same HPLC-purified peptide fraction The latter clones all reacted with the

Table 3. No influence of an H-Y mismatch on GVHD. Results of H-Y typing according to the GVHD status in HLA-A1 and HLA-A2 donor/recipient pars

\begin{tabular}{|c|c|c|c|c|}
\hline \multirow[t]{3}{*}{$\begin{array}{l}\text { Donor/recipient } \\
\text { parrs }\end{array}$} & \multicolumn{2}{|c|}{ HLA A1 } & \multicolumn{2}{|c|}{ HLA AZ } \\
\hline & \multicolumn{2}{|c|}{ GVHD } & \multicolumn{2}{|c|}{ GVHD } \\
\hline & yes & no & yes & no \\
\hline male/male & 5 & 9 & 16 & 11 \\
\hline fernale/female & 9 & 7 & 17 & 12 \\
\hline male/female & 8 & 1 & 18 & 12 \\
\hline female/male & 6 & 5 & 18 & 10 \\
\hline not tested & 0 & 0 & 2. & 1 \\
\hline total pars & 28 & 22 & 71 & 46 \\
\hline
\end{tabular}

FIDSYICQV synthetıc peptide, earlier identified as the HLA-A2restricted $\mathrm{H}$-Y T-cell epitopes derived from SMCY (Table 2) (38) Simmons et al (39) observed that HLA-B27-presented peptudes that are produced and recognized in B27-transgenic rats are not encoded by Smcy, even though the gene seems to be necessary for their generation Hence, there is evidence for a trans-mediated effect of Smcy in giving rise to these peptıdes Interestungly, additional murme studies demonstrated that $\mathrm{H}-\mathrm{Y}$ peptides could be products of genes (other than Smcy) on the Y chromosome (40)

The Smcy was earlier reported by Agulnık et al as a new mouse $Y$ chromosome gene having its human homologue SMCY mapping to the same Yq deletion interval as the mHag $\mathrm{H}$-Y-controlling locus (41) The latter authors demonstrated the evolutionary conservation of the Smcy gene by the isolation of Smcy homologous from human and horse genomic fragments (41) In view of the latter notıon, we investigated whether the mHag are evolutionarily conserved between human and non-human primates Indeed, human HA-1, HA-2 and $\mathrm{H}-\mathrm{Y}$ peptides can be recognized on the cell surface of non-human primate cells transfected with human class I genes by our human HA-1-, HA-2- and H-Y-specific class I-restricted CTL clones Furthermore, the $\mathrm{mH}$ peptides could be eluted from HLA-A2 1 molecules expressed on the transfected nonhuman primate cells This implies that the human $\mathrm{mH}$ peptides have been conserved for at least 35 million years (42) Indeed, concurrent with our latter study, Kent-First et al (43) demonstrated the expression of the SMCY gene in early primate development Moreover, the SMCY gene was shown to be widely expressed $(41,43)$ This is in concordance with our previous mHag H-Y tissue distribution studies, wherem we demonstrated ubiquitous expression of the human mHag H-Y (44) The precise function of the SMCY gene is still not known It is expressed very early in embryogenesis (41) SMCY is homologous to SMCX (located on the $\mathrm{X}$ chromosome) at the amuno acid level at $844 \%$ (43) SMCY (and SMCX) protems share sigmificant sequence homology to retmoblastoma-binding protein suggesting that the SMCY gene may code for a transcription factor (43)

\section{The male-specific mHag $\mathrm{H}-\mathrm{Y}$ - clinıcal relevance}

It has been suggested that GVHD is more frequent in male recipients of marrow from female donors (45) This effect was seen primarly with female donors who had been pregnant or had received a transfusion (45) Indeed, the above-described $\mathrm{H}-\mathrm{Y}$ responses (Table 1) were preceded by thorough in vivo sensitization events However, a mismatch for $\mathrm{H}-\mathrm{Y}$ between donor 
Table 4. Characteristics of HLA class I-restricted mHag

\begin{tabular}{|c|c|c|c|c|c|c|c|}
\hline \multirow{3}{*}{ Restriction molecules } & $H Y$ & HA 1 & $\mathrm{HA}_{2}$ & $\mathrm{HA} 3_{3}$ & $\mathrm{HA} 4$ & HA 5 & References \\
\hline & $\mathrm{A} 1 \mathrm{~A} 2$ & & & & & & \\
\hline & B7 B60 & $\mathrm{A} 2$ & $\mathrm{~A} 2$ & A1 & $\mathrm{A} 2$ & $\mathrm{~A} 2$ & 919208587 \\
\hline Mendelian segregat on & & yes & yes & yes & yes & yes & 86 \\
\hline $\begin{array}{l}\text { Phenotype frequency } \\
\%\end{array}$ & 50 & 69 & 95 & 88 & 16 & 7 & 85 \\
\hline Tissue distr bution & broada & limited & lımited & broad & broad & limited & 44 \\
\hline TCR usage & variable & skewed & variable & not tested & not tested & not tested & 88 \\
\hline
\end{tabular}

aexpression on hematopo etic and non hematoporetic cell lineages

bexpression on hematopo etic cell lineages

and recipient, with the $\mathrm{H}-\mathrm{Y}$ present in the male recipient and not in the female donor, did not lead to an increase in GVHD in our recent study (46) Table 3 summarizes the results of typing for H-Y according to the GVHD status in 50 HLA-A1- and 117 HLA-A2-matched donor-recipient parrs Neither in the HLA-A1 nor in the HLA-A2 pairs is there a significantly mcreased frequency of GVHD in the sex mismatch (1 e female donor/male recipient) combination

The absence of an $\mathrm{H}-\mathrm{Y}$ effect was observed earleer by Ramsay et al (47) Also, in zero-mismatched living donor renal transplants, no H-Y effect could be demonstrated (48) Immunodominance amongst the mHag as well as absence of synergistic effects between CTLs and Th cells in mounting an efficient mHag immune response (as discussed below) may explain these apparently controversial reports

\section{The non-Y-lınked $\mathrm{mHag}-\mathrm{mHag}$-specific T-cell subsets and GVHD}

Besides the Y-linked mHag, one can assume that, as in the mouse, the human genome has an abundance of $\mathrm{mH}$ lociencoding proteins that generate $\mathrm{mH}$ peptides that are either processed via the MHC class I pathway or presented in the context of MHC class II Boch mHag-specific class I-restricled CTLs and class II-restricted Th cells are probably mediatıng GVHD in HLA-matched BM transplants In the mouse, a varıety of studies has been carried out to explore the identity and function of cells responsible for GVH reactions After the imitial exper1ments of Boak \& Wilson (49), who showed that allogeneic lymphord cell populations devord of donor 'T' cells do not induce GVHD, and those of Korngold \& Sprent (50), who showed that, by removing mature $T$ cells from the marrow, lethal GVHD across minor $\mathrm{H}$ barriers could be prevented, the question of which donor I-cell populations are involved in the mduction of GVHD was largely surveyed in the murine model The T-cell subsets initiatıng GVHD can differ for each strain combmation $(51,52)$ It has also been reported that the $T$ cells involved in acute GVHD were found to be different from the clones established during the chronic phase of the disease (53) Although CD8 $\mathrm{T}$ cells are often reported to be involved in murme GVHD models $(50,54)$, in some stram combinations CD4 T cells can also mediate GVHD $(55,56)$ Both T-cell subsets have the potential to cause GVHD $(57,58)$ In man, the presence of a reduced number of $\mathrm{CD} 4$ cells in the donor marrow inoculum appeared to be compatible with slow but sustamed engraftment and a low incidence of serious acute GVHD (59) CD8 T-cell depletion in HL.A-1dentical sibling transplants reduces the incidence of GVHD $(60,61)$ On the other hand, in vitro observed mHag-specific CTL responses did not necessarıly correlate with the development of human GVHD either on the bulk or on the CTL precursor frequency level $(62,63)$ The same phenomenon was previously noticed in a murme GVHD model (64) and confirmed on the CTL precursor level as well (65)

Several reports have demonstated the presence of ant1-host mHag-specific CTLs in patzents suffering from GVHD after HLAgenotypically identical BMT $(62,66-72)$ Also, class IIrestricted ant1-host CTLs with a CD4 phenotype were observed In a patient suffering from severe GVHD after allogeneic BMT (24) In addition to CTLs, in vitro studies reportming on host directed Th cells have been described in patients having GVHD (67, 73-75) Van Els et al (76) reported on the long-term kinetics of Th cells in response to host mHag in 16 patients and demonstrated that significant Th-cell activity in vitro correlates with clinical acute GVHD These ant1-host Th cells carry the CD4 phenotype and recognize mHag in the context of HLA-DR and -DP (77) Post-transplant host-directed Th-cell responses measured at the Th-cell precursor level correlate with GVHD (78) Prior to HLA-identical BMT, putatıve mHag-specific Th-cell precursor frequencies can be measured $(79,80)$ In addition to ant1-host-reactive CD4 T' cells, IL-2-secretming CD8 T cells are also detected prior to HLA-1dentical sibling BMT (81) 
Table 5. Characteristics of human mHag

\begin{tabular}{ll} 
- MHC restricted recognition by T cells & References \\
\hline $\begin{array}{l}\text { presentation via various class I } \\
\text { and class II molecules }\end{array}$ & $8590-96$ \\
- Varlable phenotype frequencies & $24747797-99$ \\
- Mendelian segregation & $8590-99$ \\
- Tissue distribution & $869092-98$ \\
limited and ubiquitous & 447196100
\end{tabular}

The non-Y-lınked $\mathrm{mHag}$ - cellular recognition

Our first non-Y-linked mHag cellularly identified on the clonal level originated from a male acute myelogenous leukemıa (AML) patient transplanted with BM from an HLA-Identical female sibling donor His clinical recovery, however, was complicated by severe acute and chronic GVHD The initial experiment demonstrated that the post-transplant lymphocytes had strong cytotoxic actıvity against the patient's own pretransplant lymphocytes but not against the lymphocytes of his HLA-1dentical donor (66) This observation in itself supported the notion that, whatever the target determmant recognized by the latter CTLs, the HLA-genotypically identical donor and recipient differed for it From additional analysis of the patient's posttransplant CTL activities, it became apparent that the antigen (which we designated mHag HA-1) was not only present on the patient's own pretransplant cells, but could also be detected on lymphocytes from 2 out of 3 haplo-identical siblings, as well as on the lymphocytes of the parents and on the lymphocytes from a large number of unrelated healthy individuals The antigen HA-1 could be recognized by the patient's post-transplant CTLs only if one of the patient's HLA class I antigens was present on the target cells (82) Consequently, HA-1 is recognized in an MHC-restructed fashion, an event comparable to the recognition of $\mathrm{H}-\mathrm{Y}$ With respect to our earher studies on the impact of sex mismatch in BMT, the in vitro observed CTL response in this female/male donor-recipient combination appeared not to be directed against $\mathrm{H}_{-} \mathrm{Y}$

Next, we armed at both confirmation and extension of the latter results regarding the possible impact of polymorphic genetrc systems other than HLA on the development of GVHD in man For this purpose, we investigated post-transplant lymphocytes from a series $(\mathrm{N}=34)$ of recipients of HLA-1dentical BM grafts for the presence of ant1-host CTL activity Post-transplant lymphocytes from 21 out of 25 patients suffermng from GVHD demonstrated CTL activity which was directed agaunst the patient's own pretransplant lymphocytes (83) Hostdirected CTLs could be demonstrated in 6 out of 9 patients suf fermg from acute GVHD grade 2 or more Furthermore, in 15 out of 16 patients with chronic GVHD, ant1-host CTL activity was also observed It is worth noting that such CT'Ls can be derived from either male or female patients suffering from different hematologic malıgnancies prior to BMT Similar to the imitial antı-host-specific CTLs HA-1 (as discussed above), we next endeavored to uncover the specificity of the target struc tures recognized by some of the ant host CTLs (Table 4) Five (including HA-1) out of 21 anti-host CTL populations underwent comprehensive analyses at the population level as well as in families Comparable to HA-1, ant1-host CTLs derived from the second, third, fourth and fifth patient were found to be directed against mHag-designated HA-2,-3,-4 and -5, respectuvely, requiring self-HLA class I antigens for their recognition These conclusions are based on the reaction patterns exhibited by CTLs HA- 1 to HA-5 agamst a panel of $\mathrm{N}=100$ unrelated healthy indıviduals

The common denominator of HA-1-, 2-,-4- and -5- specufic CTLs is the preferential use of the MHC class I restriction molecule HLA-A2 (Table 4) Whether this reflects the relatuvely high phenotype frequency of HLA-A2 1 ( e $49 \%$ in the Caucasian population) or suggests that HLA-A2 1 is optumally equipped to serve as the template for peptide presentation is unclear According to the latter proposition, it is of interest to note that allelic differences exist in the interaction of MHC class I molecules with transporters associated with ant1gen processing (84) Among other HLA alleles, HLA-A2 shows that a high affinity for TAP is required for translocation of cytosolic peptıdes, such as minor H peptides $(84 a, 84 \mathrm{~b})$ In add-tion, however, it is possible that TAP supports correct folding and loading of a subset of MHC class I molecules (84)

Table 4 also shows the results of the phenotype frequency analyses carried out for mHag HA-1 to HA-5 These studies revealed that some mHag, 1 e HA-1, HA-2 and HA-3, appeared frequently (69-95\%), whlle others, 1 e HA-4 and -5, occurred with lesser $(7-16 \%)$ frequencies in the healthy population (85) An analysis of their genetic trats demonstrated a Mendelyan mode of inheritance (Table 4) (86) These four antigens can each be considered as the product of a gene with one allele expressing the detected specificity, and one or more alleles not expressing it Although our famlly data did not provide suffi clent information concerning linkage between the different $\mathrm{mH}$ loci themselves and HLA, all our tests were compatıble with the hypothesis that these lori are independent of each other and independent of HLA (86) The CTL clones listed in Table 4 were also used to analyze functıonal expression (1 e 
Table 6. Specificity analysis of mHag-specific CTL clones

\begin{tabular}{|c|c|c|c|c|}
\hline UPNa & sex do/rec & CTL lines & $\begin{array}{l}\text { no of clones } \\
\text { analyzed }\end{array}$ & $\begin{array}{l}\text { mHag } \\
\text { specificties }\end{array}$ \\
\hline \multirow[t]{2}{*}{1} & female/male & HA 1 & 7 & HA 1 \\
\hline & & & 9 & unknown \\
\hline \multirow[t]{3}{*}{4} & femalef́female & HA 4 & 8 & $\mathrm{HA} 4$ \\
\hline & & & 10 & HA 1 \\
\hline & & & 11 & unknown \\
\hline \multirow[t]{3}{*}{5} & male/female & HA 5 & 4 & HA 5 \\
\hline & & & 11 & HA 1 \\
\hline & & & 16 & unknown \\
\hline
\end{tabular}

patients who suffered from severe GVHD

read-out is cell-mediated-lympholysıs) of the mHag on varıous tıssues and cells Differential expression was observed some, 1 e H-Y, HA-3 and HA-4, are ubiquitously expressed, whereas the expression of other mHag, 1 e HA 1 and HA 2, is limited to cells of the hematopoietic lineage only (44) The additional information on the TCR usage for recognizing the MHC/HA-1 mHag ligand (88) will be touched upon in more detall later in this paper

In circumstances simular to ours, several other investigators also described the cellular identufication of more (yet a rela tively small number) non-Y-Imked mHag specificities (for an overview see (89)) The characteristıcs, as presented for $\mathrm{H}-\mathrm{Y}$ and HA-1 $10 \mathrm{HA}-5$ (Table 4), are representat1ve for other human mHag Identıfied so far $(24,44,71,74,77,85,86,90-100)$ Table 5 summarzes the general features presently known for human mHag a) recognition by $T$ cells in association with varıous MHC class I and MHC class II molecules, b) occurrence with variable phenotype frequencies in the random (though HI.A-restricted) population, c) segregation in a Mendelian fashion, and d) either limited or ubiquitous cell and tissue expression. It is important to note that these conclusions are drawn from the outcome of functional in vitro cellular assays It is almost superfluous to state that confirmative studies on the molecular level need to be carried out

\section{The non-Y-lınke $J \mathrm{mHag}$ - bıochemıcal Identificatıon}

Proteins of (retrc) viral, foreign or self-origin located in ER, cytosol or any other organelle can give rise to peptides immunogenic to class I-restricted CTLs and can represent transplantation barriers (101-105) With respect to the non-Y linked classical mHag, the mouse maternally transmitted antigen (Mta) was the first one identified at the molecular level (106) This mitochondrial $\mathrm{H}$ antigen is a peptide derived from the ammo terminus of the ND1 protem (15)
Four alleles have been detected at one locus, each different by a single ammo acid (106) The first human non-Y-linked mHag biochemically identıfied was HA-2 (16) The HLA-A2bound HA-2 peptide most probably originates from an as yet undentıfied member of the non-filament-formung class I myosin famly, a large family of protems that are unvolved in cell locomotion and organelle transport (Table 2) At present, we are mvestigating whether, indeed, a class I myosin gene is the source of the HA-2 peptide Identification of the HA-2 gene will provide the basis for its differential expression in the population (Table 4) Its allehic polymorphism can be a result of presentation of homologous but non-1dentical peptıdes, a fallure to present a peptide because it has lost 1ts MHC-anchor residue or polymorphism in the class I antigen-processing system The amino acid sequence of the HA-1 mHag has just been elucldated as well (J M M Den Haan et al manuscript in preparation)

\section{The non-Y-lınked mHag - clinıcal relevance}

The putatıve influence of known mHag disparities between HLA-identical BM donors and recipients on the development of GVHD has been retrospectively analyzed Elkıns et al (107) analyzed 67 parrs for incompatibility for mHag W1 in relation to GVHD No influence of W1 on GVHD could be demonstrated because the number of $\mathrm{W} 1$ mismatches was too low (1 e there was a high phenotypic frequency) The study by Behar et al (108) dealt with allehc differences between donor and recipient for the polymorphic adhesion molecule $\mathrm{CD} 31$ CD3 1 mismatches between BM donor and recipient are assoc1 ated with an increased risk of severe GVHD grade 3 or 4 $(\mathrm{P}=0$ 004) The platelet-endothelial-cell adhesion molecule 1 (CD31) has a broad expression, and it is constututively expressed on vascular endothelial cells, BM stem cells, platelets and leukocytes (108) Interestmgly, ant1-CD3 I monoclonal. antibodies seemed to differentıally recognize the allelic forms No CD3 1-specific T-cell responses were reported, which sepa rates this transplantation antigen from the classical ones described in man and rodents earleer In a subsequent study comprising a large series of BM donor/recipient pairs, the postulated correlation between CD31 matches and occurrence of severe GVHD could not be confirmed (109)

We analyzed the influence of mHag HA-1, $-2,4$ and -5 mismatches between HLA-identical BM donor/recipient parrs (i e BM donor mHag-negative and BM recipient mHag-positive) on the occurrence of acute GVHD grade 2 or more The results in adult patıents can be summarızed as follows a mismatch for HA-1 and/or HA-2, -4, -5 was significantly assocl- 
Table 7.

\section{A. HA-1 effect analyzed on GVHD}

\begin{tabular}{|c|c|c|c|c|}
\hline & \multicolumn{2}{|c|}{$\begin{array}{c}\text { Adults and Children } \\
\text { GVHD }\end{array}$} & \multicolumn{2}{|c|}{$\begin{array}{l}\text { Adults } \\
\text { GVHD }\end{array}$} \\
\hline & no & yes & no & yes \\
\hline HA $1 \#$ & 2 & 11 & 0 & 10 \\
\hline$H A 1=$ & 50 & 52 & 28 & 43 \\
\hline Odds ratıo & \multicolumn{2}{|c|}{54} & \multicolumn{2}{|c|}{$\infty$} \\
\hline $95 \%$ confidence interval & \multicolumn{2}{|c|}{1056} & \multicolumn{2}{|c|}{$13 \infty$} \\
\hline$P$ value ( 2 sided) & \multicolumn{2}{|c|}{005} & \multicolumn{2}{|c|}{002} \\
\hline
\end{tabular}

B. No subdominant $\mathrm{H}-\mathrm{Y}$ effect on GVHD analyzed in $102 \mathrm{HA}-1$ matched patients

\begin{tabular}{lcc} 
& \multicolumn{2}{c}{ GVHD } \\
\cline { 2 - 3 } HY & no & yes \\
HY $=$ & 37 & 39 \\
& 13 & 13 \\
Odds ratio & & \\
$95 \%$ confidence interval & 095 \\
P value (2 sided) & 035255 \\
& 1000
\end{tabular}

ated with GVHD ( $\mathrm{P}=0$ 006) The main effect of the significant association with the development of GVHD appeared to be caused by an HA-1 mismatch, since a single HA-1 mismatch between donor and recipient reached a $\mathrm{P}$ value of 002 (Table 7A) (46) It is clear that these studies need confirmation in larger groups of patients

\section{Immunodominance of $\mathrm{mHag}$}

In 1966, Graff, Hrldemann \& Snell, usıng a panel of congenıcresistant mice differing at multuple $\mathrm{mH}$ loci, concluded from their skin allograft studies as follows "The strengths of the barriers imposed by the non $\mathrm{H}-2$ histocompatibility locı were quite variable, the median survival tumes for the various loci ranging from 15 to $>300$ days" (110) Subsequent serıes of murme skm-graftıng responses, in vivo priming expermments and GVHD models clearly showed that the immune responses were dominated by a small number of mHag Hereby the phenomenon of immunodommance of murme mHag was clearly established (111-116) Later, the immunodominance was also verified on the mHag peptude level Bulk CTL responses generated across multiple $\mathrm{mH}$ barrıers appeared to be directed against only a few $\mathrm{mH}$ peptides (117-120) Whether or not a single mHag disparity can cause GVHD, an expermental condition whıch will never occur in man, is not yet clear $(121,122)$
The fact that a significant number of BM transplants between HIA-1dentical siblings (with optimal immunosuppression) do not lead to GVHD suggests a hierarchy in mHag immunogenicity (123) 'Two sets of our data are indicative for mHag ummunodominance Firstly, CTL clones reactive to the same mHag HA-1 were obtaned from peripheral blood lymphocytes of 3 individuals each transplanted across a multiple and probably distunct mH barrier (Table 6) (85) Secondly, in the study mentioned earlier of 148 BM HLA-identical donor/recipient pairs, investigating the influence of mHag HA-1 to HA-5 mismatching on the development of GVHD, a mismatch of only HA-1 was significantly associated with GVHD in adult patents (46)

The herarchy in mHag immunodominance also imples the existence of subdommant mHag, as exemplified for murıne mHag previously (113) We observed the absence of an $\mathrm{H}-\mathrm{Y}$ mismatch effect (discussed above under the heading The malespecific mHag H-Y - clinical relevance) (Table 3) In view of the existence of subdominant mHag, we analyzed our mHag disparities and human GVHD data by omission of the dommant HA-1 antigen (Table 7)

No H-Y effect could be demonstrated in 102 HA-1matched BM donor/recipient pairs (Table 7B) It is of interest to note that Wettstem (124) reported on the immunodommant behavior of an autosomal murme mHag H-3 over the $\mathrm{H}-\mathrm{Y}$ antigen in the generation of CTLS

\section{How to become a "wicked" mınor}

We now know that mHag are naturally processed protems of peptidic nature Any protem, whether it is cellular- or membrane-associated, can give rise to $\mathrm{mH}$ peptides To become a "wıcked" minor, a condition sine qua non is that the minor protein source must possess some degree of polymorphism The immunogenicity of a potentially large number of mHag is restructed by various factors Some of the possible factors underlying the mHag immunodommance, illustrated by as yet very little information on human major minors, will be discussed below

The synergistic effects of MHC class I $\mathrm{mHag}$-specific CTLs and MHC class II mHag-specific Th cells promoting an effective $\mathrm{mH}$ Immune response

In the murme model, an early report of an effective $\mathrm{H}-\mathrm{Y}$ response brought about by $\mathrm{H}$-Y-specific CTLs and Th cells was published by Von Boehmer \& Haas (125) Genetic analysis of loci encoded with the murine $\mathrm{H}-3$ and $\mathrm{H}-4$ regions has revealed that the existence of separate locı encoding Th-cell and CTL $m H$ epitopes was required to induce a CTL response in vivo, 


\begin{tabular}{|c|c|c|}
\hline Anti host $T$ cell & \multicolumn{2}{|c|}{ GVHD status } \\
\hline activities & no & acute $>2$ \\
\hline CTL and Th & 2 & $\overline{10}$ \\
\hline CTL alone & 2 & 2 \\
\hline Th alone & 0 & 1 \\
\hline no CTL no Th & 3 & 0 \\
\hline
\end{tabular}

indicating the relevance of Th-CTL cell collaboration in the ant1-H3 and ant1-H4 immune response $(126,127)$ With regard to the murine $\mathrm{mH}-\mathrm{H} 3$ complex, recent genetic linkage studies demonstrated that the CTL and Thepitope are encoded by distinct genes, the $\mathrm{H} 3 \mathrm{a}$ (encoding the CTL epitope) and the H3b (encoding the Th epitope) map approximately $12 \mathrm{cM}$ apart on the mouse chromosome 2 (128) Nonetheless, CTI and Th epitopes can also be encoded by the same gene From a melanoma patient, CD4 T cells ssolated from tumor-mfiltrating lymphocytes recognized an immunodominant epitope coded for by a gene which also encodes class I CD8 T-cell epitopes (129) As discussed above (under the heading mHag-specific T-cell subsets and GVHD), it is likely that both CTL and Th-cell subsets play a role in the development of human GVHD We analyzed 20 patzents to determme whether ant1-host CTL and Th-cell responses occurred simultaneously at different times postHLA-Identical sibling BMT Table 8 shows anti-host CTL and Thcell responses in 10 out of 13 patients with severe GVHD On the contrary, in the "no GVHD" group of patients, both CTL and Th-cell responses were detectable in only 2 out of 7 patients analyzed These prelımmary results support the notion that CTL and Th mHag epitopes collaborate in the antı-host GVHD immune responses in man as well Naturally, identufication of the CTL and Th mHag involved in these responses needs to be determined

\section{T-cell repertorre dependency}

Immunodominance may also depend on the avallable TCR repertoire A single murme class I allo peptide appeared dommant in V $\beta 8$-positive but not in ${ }^{7} \beta 8$-negative mouse strains, indicating that the dominant pertide recognition was dependent upon Vß8-positive $T$ cells (130) We observed $\mathrm{b}_{\gamma}$ analyzing TCR usage of 12 clones derived from 3 individuals (Table 6 UPN 1 , $4,5)$ that the TcR $\beta$ chams all used the TCR $\beta$ V6S9 gene segment and showed remarkable similaritzes within the N-D-N regions (Table 4) (88)

\section{Peptide affinity}

One of the mechanisms of immunodominance also resides at the level of peptide/MHC-binding properties The affinity of
MHC class I-peptade binding is crucial for the outcome of an immune response, even in the situation of subdominant epitopes (131) Murine mHag T-cell responses appeared to be influenced by differential bindung of the minor peptide to class I molecules (132) Using an equilibrium-binding assay to measure relative affinities, the mHag HA-2 and the H-Y peptide are classified among the highest affinity naturally processed peptıdes that have been identified to date The concentration of the HA-2 peptide as competitor peptide that resulted in 50\% inhibition of the lodinated peptide binding (IC50) was 67 $\mathrm{nM}$, and the IC50 value for H-Y was $16 \mathrm{nM}$ (Table 9), the IC50 values for other published peptides vary from 11-214 nM for HLA-A2 $(133,134)$

Table 9 also illustrates the half-maximal lysis values of the human mHag peptides HA-2 and H-Y The synthetıc peptide concentrations required to reconstitute $50 \%$ spectic CTL recogmition are low compared to the values of the T-cell epitopes reported earlier (135) This reflects high affinity of the peptide for MHC or high affinity of the T-cell receptor

\section{Production of cytokines}

Antigen presentation by professional antıgen-presentıng cells (APCs) accounts for the primary mituation process of GVH pathogenesis Cytokines do play a significant role in both acute and chromc GVHD (see (136) for a comprehensive review) In a murme model, IL- $1 \alpha$ has been postulated as a critical effector molecule in mHag-directed GVHD (137) Antıbodies to TNF $\alpha$ could completely prevent lethal GVHD induced in mH-disparate mice (138) Also, the GVHD-mducing potential of some $\mathrm{mH}$ antigen-specific T-cell clones has been shown to correlate with the levels of TNFo clones produced in vitro (139) T-cell-derived lymphokınes (IL-3, IL-4, and CSF) are produced in vivo and in vitro in response to mHag The properties of these produced activities are similar to those that responded to irradiated syngeneic cells, but there was a difference in the time course of the lymphokme production between GVH mHag-disparate mice and the syngeneic transplant mice (140)

In man, by means of a GVHD-predictive assay, the in vitro GVH reactivity to host skm tissue was found to correlate with the levels of TNFo and INFy secreted into the supernatant of HLA-matched patıent/donor mixed lymphocyte cultures (141)

Tissue distribution

Presentation of immunogenic MHC/mH peptide complexes by professional APCs is essential for induction of anti-host cellular immune responses In this regard, it is worthwhle mentioning that the human mHag HA-1, which is shown to be significantly associated with GVHD (as discussed earlier), is clearly 

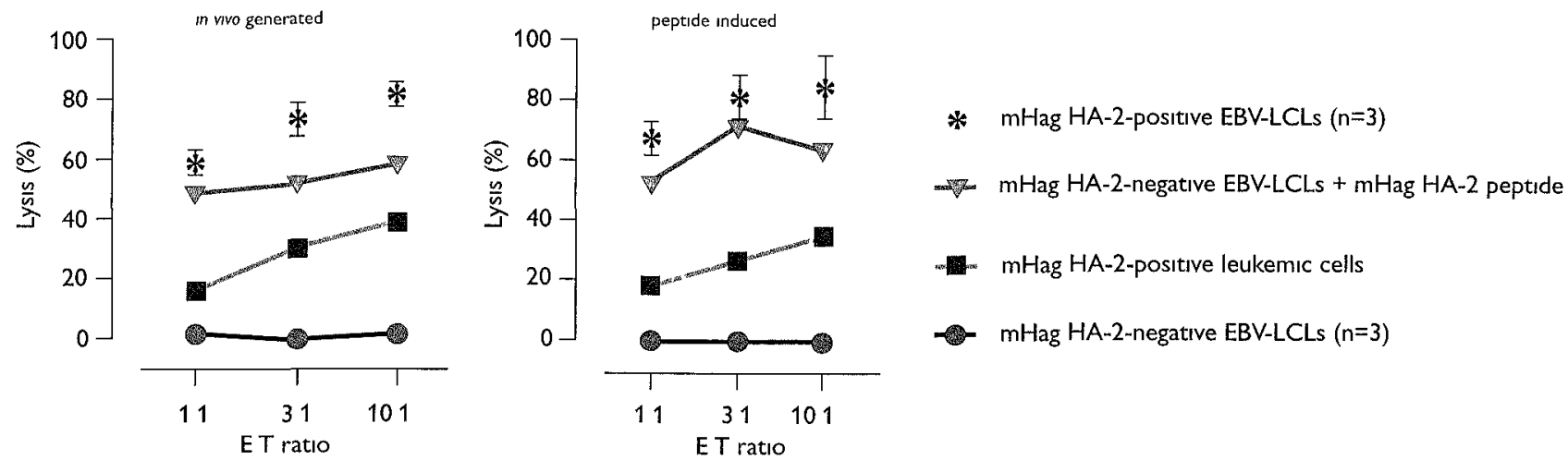

Fig. 2. Generation of mHag peptide-specific CTLs. Peripheral

blood lymphocytes were pulsed with the HA-2 synthetic

peptıde and used as stımulator cells for autologous $\mathrm{T}$ cells The

$\mathrm{T}$ cell line obtained was cloned under limitıng dilution

conditions 03 cell/well

leucocyte therapy is associated with a significant occurrence of marrow aplasıa and GVHD (160) In addition, donor leucocyte infusions for relapsed ALL and AML patients are far less effective $(160,161)$ Second, adoptsve immunotherapy with donor Epsteın-Barr virus (EBV)-specific CTLs eradicated EBV-associated post-transplant lymphoproliferatıve disease without causing GVHD (162) Third, adoptive transfer of cytomegalovirusspecific T-cell clones were effective in restoring immunity (163)

The advantage of using mHag-specıfic CTLs as adoptive mmunotherapy of leukemia lies in their restricted and specific target cell damage Thus, we will take advantage of three of the known characteristics of human mHag (Table 5), $1 \mathrm{e}$ 1) MHC-restricted recogmition by $T$ cells, 2) varıable phenotype frequencies, 1 e mHag polymorphism, and 3) restricted tıssue distribution Moreover, since mHag are clearly expressed on carculatung leukemıc cells and clonogenıc leukemıc precursor cells of both myelord and lymphoid origin $(164,165)$, both types of leukemias can be targeted We wll generate mHag peptide CTLs ex vivo from mHag-negatıve BM donors for mHag-positive patients Ous prelıminary results are promısing We prepared peptıde-specific CTL clones from an HLA-A2-positıve mHag HA-2-negauve healthy blood donor by pulsing autologous APCs with HA-2 synthetic peptide Prolfferatıng clones were expanded and tested for specific cytotoxic activity aganst mHag HA-2-positive and mHag HA-2-negative EBVLCLs and HA-2-negatıve EBV-LCLs loaded with the HA-2 peptide and aganst mHag HA-2-positive leukemic cells The results of one mHag peptide-induced CTL clone are shown in Fig 2 The results are compared with those obtamed with our pre-

existıng (in vivo induced) mHag HA-2-specific CTL clone assayed agannst the same target cells

Upon transfusion (either pre-BMT as part of the conditioning regimen or post-BM'T as adjuvant therapy), the mHag peptide-specific CTIs will eliminate the mHag-positıve patıent's leukemic cells and, if of the patient's origin, also the patient's hematopoietıc cells but will spare the patient's non-hematopoietıc cells If necessary, subsequent $m$ Hag negatıve donor BMT will restore the patient's hematopoietic system A universal option would be to generate "prefab" mHag peptıde-specific CTLs by using mHag-negative healthy blood donors with frequent HLA-homozygous haplotypes Patients who are HA-1 - or HA-2-positive (and therr BM donors HA-1- or HA-2-negative) and who match the HLA typing of the CTL donor can be treated with these "ready to be used" allo HA-1 or HA-2 peptıde-specific CTLs Transduction of these CTILs with a suicide gene makes elimination of the CTLs possible in case adverse effects occur Future research should also focus on the possible need for mHag Th epitopes for optımal therapeutic efficacy

Immunodominant mHag

- BM donor selection

- GVHD prophylaxis/treatment

mHag with broad tissue distribution

- induction of tolerance

$m$ Hag with restricted tissue distribution

- adoptive immunotherapy of leukemia
Table 10. Human minor histocompatibility antigens: new concepts for marrow transplantation and adoptive immunotherapy 


\section{References}

1 Snell GD Methods for the study of histocompatibility genes

J Genet 1948,49 87-103

2 Counce S, Smith P, Barter R, Snell GD Strong and weak histocompatibility fine differences in mice and their role in the rejection of homografts of tumors and skm Ann Surg 1956,144 1988-2204

3 Graff RJ, Balley DW The non $\mathrm{H}-2$ histo compatibility loci and therr antigens Transplant Rev 1973,15 26-49

4 Schultz JS, Beals TF, Petraitis FP Tissue graft rejection in mice I Contributions of $\mathrm{H}-2$ and non $\mathrm{H}-2$ genetıc barriers Immunogenetics 1976,3 85-96

5 Zinkernagel RM, Doherty PC Restriction of in vitro $T$ cell mediated cytotoxacity in lymphocytic choriomeningitis with a syngeneic or semrallogeneic system Nature 1974,248 701-702

6 Bevan MH. The major histocompatibility complex determines suscepubility to cytotoxic T cells durected aganst minor hıstocompatibility antigens

J Exp Med 1975,142 1349-1364

7 Gordon RD, Smpson E, Samuelson LE In vitro cell mediated immune response to the male specufic (H-Y) antigen in mice

J Exp Med 1975,142 1108-1120

8 Goulmy E, Termutelen A, Bradley BA, Van Rood JJ Allormmunnty to human H-Y Lancet 1976,ii 1206

9 Goulmy E, Termıtelen A, Bradley BA, Van Rood JJ Y-antıgen kllling by $T$ cells of women 1s restricted by HLA

Nature 1977,266 544-545

10 Bjorkman PJ, Saper MA, Samraou1 B, Bennett WS, Stromnger JL, Wiley DC The foreign antigen binding site and $\mathrm{T}$ cell recognition regions of class $I$ histocompatibility antigens Nature 1987,329 512-518

11 Townsend ARM, Rotbard J, Gotch FM, Bahadur G, Waratth D, McMichael AJ The epitopes of influenza nucleoprotem recognized by cytotoxic $\mathrm{T}$ lymphocytes can be defined with short syntheuc peptides Cell 198644 959-968

12 Townsend A Recognition of mfluenza virus proteins by CTL

Immunol Res 1987,6 80-100

13 Rotzschke O, Falk K., Wallny H-J, Faath S, Rammensee HG Characterization of naturally occurring mınor histocompatıbilıty peptudes including $\mathrm{H} 4$ and $\mathrm{H}-\mathrm{Y}$

Science 1989,249 283-287

14 Falk K, Rotzschke O, Rammensee HG Cellular peptude composition governed by major histocompatability complex class I molecules Nature 1990,348 248-251
15 Fisher Lindahl K, Hermel E, Loveland BE and Wang CR Maternally transmitted antigen of mice a model transplantation antugen Annu Rev Immunol 1991,9 351-372

16 Den Haan JMM, et al Identification of graftversus host disease associated human minor histocompatıbility antigen Science 1995,268 1478-1480

17 Ezchwald EJ, Slumser CR Transplant Bull 1955,2 148-149

18 Billingham RE, Silvers WK Studies on tolerance of the $\mathrm{Y}$ chromosome antigen $\mathrm{m}$ mice

J Immunol 1960,85 14-26

19 De Bueger M, Bakker A, Goulmy L Exustence of mature human $\mathrm{CD}^{+} \mathrm{T}$ cells with genume class I restriction

Eur I Immunol 1992,22 875-878

20 Voogt PJ, et al Rejection of bone marrow graft by recipient derived cytotoxic $T$ lymphocytes against minor histocompatibulity antigens Lancet 1990,335 131-134

21 Voogt PJ, et al Minor histocompatibility antigen $\mathrm{H}-\mathrm{Y}$ is expressed in human haematopoietuc progenitor cells J Clin Invest 1988,82 906-912

22 Singal DP, Wadıa YJ, Naupaul N In vitro cellmediated cytotoxicity to the male specific $\mathrm{H}$ Y antigen $m$ man Hum Immunol $1981245-53$

23 Pfeffer PF, Thorsby E HLA restructed cytotoxicity against male specific ( $\mathrm{H}-\mathrm{Y}$ ) antigen after acute rejection of an HLA identical sibling kidney clonal distribution of the cytotoxic cells

Transplantation 1982,33 52-56

24 Faber LM, Van Luxemburg-Hexjs SAP, Veenhof WFJ, Willemze R, Falkenburg JHF Generation. of $\mathrm{CD} 4+$ cytotoxic $T$ lymphocyte clones from a patzent with severe graft-versus host disease after allogeneıc bone marrow transplantation mplications for graft-versus-leukemıa reactivity

Blood 1995,86 2821-2828

25 Horas S, Van der Poel Jj, Goulmy E Differential recognition of the serologically defined HLA-A2 antigen by allogeneic cytotoxic $T$ cells I Population studies Immunogenetics 1982,16 135-142

26 Van der Poel JJ, Pool J, Goulmy E, Giphart MJ, Van Rood JJ Recognition of distinct epitopes on the HLA-A2 antigen by cytotoxic I lymphocytes

Hum Immunol 1986,16 247-258

27 Goulmy E, Van der Poel JJ, Giphart M, Van Rood JJ Analysis of the functional epitopes on different HLA A2 molecules Immunogenetics 1984,20 13-21

28 Ezquerra A, Domenech N, Van der Poel JJ, Strominger JL, Vega MA, Lopez de Castro JA Molecular analysis of an HLA. A2 functional variant $\mathrm{Cla}$ defined by cytolytı $\mathrm{T}$ lymphocytes

J Immunol 1986,136 1642-1649

29 Goulmy E, Van Leeuwen A, Blokland E, Sachs ES, Geraedts JPM The recognition of abnormal sex chromosome constitution by HLA restricted antı-H-Y cytotoxic T cells and antibody

Immunogenetıcs $1983,17523-531$

30 Simpson E, Chandler P, Goulmy E, Disteche CM, Ferguson-Smith MA, Page DC Separation of the genetac loc for the $\mathrm{H}-\mathrm{Y}$ antigen and for testis determination on buman $Y$

chromosome

Nature 1987,326 876-878

31 Simpson E, Chandler P, Goulmy E, Ma K, Bargreave TB, Chandley AC Loss of the 'azoosperma factor' (AZF) on Yq in man is not associated with loss of HYA

Hum Mol Genel 1993,2 469-471

32 Cantrell MA, et al Deletion mapping of $\mathrm{H}-\mathrm{Y}$ antigen to the long arm of the human $Y$ chromosome

Genomics 1992,13 1255-1260

33 O'Reilly AJ, Affara NA, Simpson E, Chandler P, Goulmy E, Ferguson Smith MA A molecular deletion map of the $Y$ chromosome long arm defining $\mathrm{X}$ and autosomal homologous regions and the localisation of the HYA locus to the proximal region of the Yq euchromatin Hum Mol Genet 1992,1 379-385

34 Hunt DF, et al Characterization of peptides bound to class I MHC molecule HLA-A2 1 by mass spectrometry Scrence 1992,255 1261-1263

35 Wang W, et al Human H-Y a male-specific histocompatibility antigen derived from the SMCY protein Science 1995,269 1588-1590

36 King TR, et al Deletion mapping by immunoselection aganst the $\mathrm{H}-\mathrm{Y}$ histocompatibility antigen further resolves the Sxr' region of the mouse $\mathrm{Y}$ chromosome and reveals complexaty of the Hya locus Genomics 1994,24 159-168

37 Scott DN, et al Identrfication of a mouse male specific transplantation antıgen $\mathrm{H}-\mathrm{Y}$ Nature 1995,376 695-698

38 Meadows $\mathrm{L}$, et al The $\mathrm{H}-\mathrm{Y}$ antigen presented by HLA-A*0201 contains a post translationally modified cysteme residue a common pepude modification that significantly affects $\mathrm{T}$ cell recognition Immunity 1997,6 273-281

39 Simmons WA, et al Novel HY pepude antigens by HLA-B27

J Immunol (In press)

40 Greenfield A, et al An H-YD' eprope is encoded by a novel mouse $Y$ chromosome gene

Nature Genetics $1996,14474-478$ 
41 Agulmk AI, Mitchell MJ, Lerner JC, Woods DR, Bishop CE A mouse Y chromosome gene encoded by a region essential for spermatogenesis and expression of male specific munor histocompatibility antigens Hum Mol Genet 1994,3 873-878

42 Den Haan JJM, et al Conservation of mmor bistocompatıbility antrgens between human and non-human primates

Eur J Immunol 1996,26 2680-2685

43 Kent-First MG, Maffitt M, Muallem A, Brisco P, Shultz J, Ekenberg S Gene sequence and evolutionary conservation of human SMCY Nature Genetics 1996,14 128-129

44 De Bueger M, Bakker A, Van Rood JJ, Van der Woude F, Goulmy E Tissue distibution of human minor histocompatibility antigens ubiquitous versus restricted tissue distribution indicates heterogeneity among human cytotoxic T' lymphocyte defined non MHC antigens

J Immunol 1992,14 1788-1794

45 Report from the International Bone Marrow Transplant Registry

Bone Marrow Transplant 1989,4 221-228

46 Goulmy E, et al Mismatches of mmor histocompatiblity antigen between HLAidentical donor and recipients and the development of graft versus-host disease after bone marrow transplantation N Engl J Med 1996,334 281-285

47 Ramsay NKC, et al A randomized study of the prevention of acute graft versus-host disease N Engl J Med 1982,306 392-397

48 Ellison MD, Norman DJ, Breen TJ, Edwards $E B$, Davies DB, Dally OP No effect of H-Y minor histocompatıbility antıgen in zeromismatched living-donor renal transplants Bref communications

Transplantation 1994,58 518-530

49 Boak JL, Wllson RE Modification of the graft versus-host syndrome by ant1-lymphocyte serum treatment of the donor Clun Exp Immunol 1968,3 795-800

50 Korngold R, Sprent J Lethal graft-versu, host disease after bone marrow transplantition across minor histocompatibility barriers in mice prevention by removing mature T cells from maliuw

J Exp Med 1978,148 1687-1698

51 Hamiton BL L3T'4 positive T ells participate in the induction of graft vs host disease in response to munor histoccmpatibility antigens

J Immunol 1987,1392511-2515

52 Berger M, Wettstem 听, Korngold R T cell subsets involved in lethal graft-versus-host disease durccted to ummunodomunant minor histocompatibility antigens

Transplantation 1994,57 1095-1102

53 Parkman R Clonal analysis of murme giaft vs-host disease I Phenotypic and functional analycis of $\mathrm{T}$ lymphocyte clones

J Immunol 1986, $1363543-3548$
54 Korngold R, Sprent $\mathrm{R}$ Features of T cells causing $\mathrm{H}-2$ restricted lethal graft-versus-host disease across minor histocompatibility barriers

J Exp Med 1982,155 872-883

55 Kindred B Prelıminary characterizatıon of the cells cause a $\mathrm{H}-2$ restricted $\mathrm{GvH}$ reaction Immunogenetıcs 1984,19 243-248

56 Korngold R, Sprent J Variable capacity of L3T4+ T cells to cause lethal graft versus-host disease across minor histocompatibilty barriers in mice

J Exp Med 1987,165 1552-1564

57 Cobbold SPO, Martın G, Waldmann H Monoclonal antıbodies for prevention of graft-versus-host disease and marrow graft rejection the depletion of $T$ cell subsets in vitro and in vivo

Transplantation 1986,42 239-247

58 Wettstein PJ, Korngold R T cell subsets required for in vivo and $m$ vitro responses to single and multupe minor histocompaubilty antigens

Transplantation 1992,54 296-307

59 Atkinson $\mathrm{K}$, et al $\mathrm{T}^{+}$cells can mutrate human graft-versus-host disease

Transplant Proc 1987,19 2879-2881

60 Champlın R, et al Retention of graft versus host leukemia using selective depletion of CD8 posituve 'T lymphocytes for prevention of graft versus host disease following bone marrow transplantation for chromic myelogenous leukemı

Transplant Proc 1991,23 1695-1696

61 Maraninchi D, et al Selective depletion of marrow $\mathrm{T}$ cytotoxic lymphocytes (CD8) in the prevention of graft-versus-host disease after allogeneic bone marrow transplantation Transpl Int 1988,1 91-94

62 Van Els C, Bakker A, Zwınderman AH, Zwaan FE, Van Rood JJ, Goulmy E Effector mechanısms in GVHD in response to minor histocompatibility antigens I Absence of correlation with CTLs

Transplantation 1990,50 62 -66

63 De Bueger M, Bakker A, Bontkes H, Van Rood JJ, Goulmy E High frequencies of cytotoxic $T$ cell precursors agamst minor hustocompatıbilıty antigens after HLA-Identical BMT absence of correlation with GVHD

Bone Marrow Transplant 1993,1 1 363-368

64 Hamilton BL Absence of correlation between cytolytuc T lymphocytes and lethal murne graft-versus-host disease in response to minor histocompatibility antigens Transplantation 1984,38 357-360

65 Fontaine P, Langla1s J, Perrault $C$ Evaluation of in vitro CTL assays as a predictive test for the occurrence of graft vs host disease Immunogenetıcs 1991,34 222-226
66 Goulmy E, Gratama JW, Blokland E, Zwaan FE, Van Rood JJ Recognition of an -as yet unknown- minor transplantation antigen by posttransplant lymphocytes from an AML. patient

Exp Hematol 1982,10 127-129

67 Tsol M S, Storb R, Dobbs S, Medull I, Thomas ED Cell mediated immunity to non-HLA antigens of the host by donor lymphocytes in patients with chronic graft-vs-host disease J Immunol 1980,125 2258-2262

68 Tsol M-S, Storb R, Santos E, Thomas ED Ant1host cytotoxic cells in patients with acute graft versus-host disease after HLA identical marrow graftung

Transplant Proc 1983,15 1484-1486

69 Irle C, Beatty PG, Mickelson E, Thomas ED, Hansen JA Alloreactive T cell responses between HLA identical siblings Transplantation 1985,40 329-333

70 Irschick E, et al Studies on the mechanısm of tolerance or graft-versus host disease in allogeneic bone marrow recipients at the level of cytotoxic $\mathrm{T}$ cell precursor frequencies Blood 1992,79 1622-1628

71 Niederwieser D, et al Correlation of minor histocompatibility antigen specific cytotoxic T lymphocytes with graft-versus host disease status and analyses of tissue distribution of their target antigens

Blood 1993,81 2200-22,08

72 Marıt EAF, et al Multuple minor histocompatıbllity antıgen disparıtıes between a recipient and four HLA identical potential sıbling donors for bone marrow transplantatron

Hum Immunol 1993,37 221-228

73 Kasten-Sportes C, Masset M, Varrm F, Devergie A, Gluckman E Phenotype and function of T lymphocytes infiltratung the skın durıng graft-versus-host disease following allogeneic bone marrow transplantation

Transplantation 1989,47 621-624

74 Reinsmoen NL, Kersey JH, Bach FH Detection of HLA restricted anti minol histocompatıblity antıgen(s) reactıve cells from skm GVHD lesions Hum Immunol 1984,1 249-257

75 Irle C, Chapus B, Jeannet M, Kaestl M, Montandon N, Speck B Detection of ant1non-MHC-directed T cell reactivity following in vivo primung after HLA identical marrow transplantation and following in vitro priming in limiting dilution cultures Transplant Proc 1987,19 2674-2677

76 Van Els CACM, Bakker A, Zwinderman AH, Zwaan FE, Van Rood JJ, Goulmy E Effector mechanısms in GVHD in response to mmor histocompatıbility antıgens II Evidence for a possible involement of proliferative $T$ cells Transplantation 1990,50 67-71 
77 Van Els C, Landvoort E, Jacobs N, Bakker A, Van Rood JJ, Goulmy E Graft versus host disease associated $T$ helper cell responses specific for minor histocompatibllity antıgen are mannly restricted by HLA DR molecules Bone Marrow Transplant 1990,5 365-372

78 Nierle T, Bunjes D, Arnold R, Heimpel H, Theobald $M$ Quantitative assessment of posttransplant host specific interleukm 2 secreting T helper cell precursors in patients with and without acute graft versus-host disease after allogenerc HLA identical sibling bone marrow transplantation

Blood 1993,81 841-848

79 Theobald M Nierle T, Bunjes D, Arnold R, Heimpel H. Host specific interleukn 2 secreting donor $\mathrm{T}$ cell precursors as predictors of acute graft-versus-host disease in bone marrow transplantation between HLA identical srblings N Engl J Med 1992,327 1613-1617

80 Schwarer AP, Jiang JP, Barrett JM, Batchelor JR Goldman JM, Lechler RI Helper T' lymphocyte precursor (HTLp) frequency predicts the occurrence and severity of acute GVHD and survival after allogeneic BMT in both recipients of genotypically HLA identical sibling (SIB) and phenotypically HLA-matched unrelated donor (MUD) marrow

Lancet 1993,341 203-205

81 Theobald M Bunjes D Pretransplant detection of human minor histocompatibility antigen specific narve and memory inter leukın-2 secreting T cells withm class I major histocompatibility complex (MHC)restricted $\mathrm{CD}^{+}$and class II $\mathrm{MHC}$ restricled $\mathrm{CD} 4+\mathrm{T}$ cell subsets

Blood 1993,82 298-306

82 Goulmy E, Gratama JW, Blokland E, Zwaau FE, Van Rood JJ A minor transplantation antigen detected by $\mathrm{MHC}$ restricted cytotoxic I lymphocytes durng graft-versus-host discase

Nature 1983,302 159-161

83 Goulmy E Lifting a tup of the vel of human minor histocompatıbility antıgens In Zander AR, Ostertag W, Afanasıev BV, Grosveld T, eds Gene Technology NATO ASI Series (94) Berlin Springer Verlag, 1996 p 353359

84 Neisıg A Wubbolts R, Zang X, Melnef C, Neefjes $\int$ Allele-specific differences in the interaction of MHC class I molecules with transporters associated with antigen processing

J Immunol 1996,156 3196-3206

84a Momburg F, et al Proteasome subunts encoded by the major histocompatibility complex are not essentral for antigen presentation

Nature 1992,360 174--177

84b Goulmy E Minor histocompatibility antigen matching actual fact or wishful thinking? Bone Marrow Transplant 1995, 15 59-62
85 Van Els C, D'Amaro J, Pool J, Bakker A, Van den Elsen PJ, Van Rood JJ, Goulmy E Immunogenetics of human minor hustocompatıbility antugens thejr polymorphism and immunodominance Immunogenetics 1992,35 161-165

86 Schreuder GMTH, et al Genetic analysis of human minor histocompatıbility antıgens demonstrates Mendelian segregation independent from HLA Immunogenetics 1993,38 98-105

87 Goulmy E, Hamilton JD, Bradley BA Ant1-self HLA may be clonally expressed J Exp Med 1979,149 545-550

88 Goulmy E, Pool J, Van den Elsen PJ Interındividual conservation of $\mathrm{T}$ cel receptor $\beta$ chain variable regions by minor histocompatibilnty antigen specific HLA. $A * 0201$ restricted cytotoxic $T$ cell clones Blood 1995,85 2478-2481

89 Goulmy E Human minor histocompatibility antigens

Curr Opm Immunol 1996,8 75-81

90 Zier KS, Elkıns WL, Pierson GR, Leo MM The use of cylotoxic $T$ cell lines to detect the segregation of a human mmor alloantgen withın familes

Hum Immunol 1983,6 117-129

91 Irlé C, Beatty PG, Mickelson E, Donnall TE, Hansen JA Alloreactive T cell response between HLA identical siblings Detection of antı tumor histocompatibiluty $\mathrm{T}$ cell clones induced in vivo

Transplantation 1995,40 329-333

92 Beck Y, et al Isolation of human munor histocompatıblity pepudes from cultured kudney cells

Transplant Proc 1993,25 162-166

93 Yamamoto J, Karyone A, Aklyama N, Kano K, Takiguchi $M$ Presentation of human munor histocompatıblity antıgens by HLA-B35 and HLA-B38 molecules

Proc Natl Acad Scı USA 1990,87 2583-2587

94 Vincı G, Masset M, Semana G, Vernant J P A human minor histocompatibility antıgen which appears to segregate with the major histocompatibility complex Transplantation 1994,58361367

95 Gubarev MI, et al Localication to chromosome 22 of a gene encoding a human minor histocompatiblity antigen

J Immunol 1996,157 5448-5454

96 Dolstra H, et al Recognition of a B cell leukemia-associated minor histocompatrbility antigen by CTL

J Immunol 1997,158 560-565

97 Mickelson EM, Beatty PG, Storb R, Hansen JA Immune responses in an untransfected patıent with aplastic anemia analysıs of cytolytic anc prohfei atjve $T$ cell clones Hum Immunol 194,10 189-201
98 Tilkın AF, Bagot M, Kayıbanda M, Vernant JP, Levy JP Human autoreactive T cell line specific for minor histocompatubility antigen(s) isolated from a bone marrowgrafted patient

Transplantation 1986,137 3772-3776

99 Nishimura M, Akaza T, Mitomı Y, Nieda M, Minamı M, Jujı T Establishment of human minor histocompatubility antigen-specific cytotoxic T cell clones resticted by HLA-DR9 Transplantation 1993,44 181-186

100 Beck Y, et al Expression of human mmor histocompatibility antigen on cultured kidney cells

Eur J Immunol 1993,23 467-472

101 Colombo MP, Jaenısch R, Wettstem PJ Endogenous retroviruses lead to the expression of a histocompatibility antigen detectable by skin graft rejection Proc Natl Acad Scl USA 1987,84 193-198

102 Wettstein PJ, Jewett L, Faas S, Brinster RL, Knowles BB SV40-antugen is a histocompatıbility antigen of SV40transgenic mice Immunogenetics $1988,27 \quad 436-441$

103 Boon $T$, Van Pel A T cell recognuzed antigemc peptides derived from the cellular genome are not protein degradation products but can be generated drrectly by transcription and translation of short subgemic regions, a hypothesis Immunogenetics 1989,29 75-79

104 Rammensee H-G, Robinson PJ, Crisantı A, Bevan MJ Resincted recognition of $\beta 2 \mathrm{~m}$ by cytotoxic $T$ lymphocytes

Nature 1986,319 502-504

105 Speiser DE, et al Nuclear myxovirusresistance protem $\mathrm{Mx}$ is a minor hıstocompatıbility antıgen Proc Natl Acad Scl USA 1990,87 202 J-2025

106 Loveland BE, Wang CR, Yonekawa H, Hermel E, Fischer Lindahl K Maternally transmitted histocompatibility antigen of mice a hydrophobic peptide of a mitochondrially encoded protem Cell 1990,60 971-980

107 Elkıns WL, Pierson GR, Storb R Study of a human minor alloantigen in relation to clinical graft-versus-host disease Bone Marrow Transpl 1987,1 397-403

108 Behar E, et al Polymorphism of adhesion inolecule CD31 and uts role in acute graft versus-host disease N Engl J Med 1996,334 286-291

109 Nichols C, et al Polymorphism of adhesion molecule CD3 1 is not a significant risk factor for graft versus host disease Blood 1996,88 4429-4434

110 Graff RJ, Hildemann WH, Snell GD Histocompatibiluty genes of mice VI Allografts in mice congenic at various non- $\mathrm{H}$ 2 histocompatibility lor 1 Transplantation 1966,4 425-437 
111 Johnson LJ, Baley DW, Mobraaten LE Angenic competition between munor (nonH 2) histocompatıbility antigens Immunogenetics 1981,13 451-455

112 Wettstein PJ, Balley DW Immunodominance in the immune response to 'multuple' histocompatıbility antigens Immunogenetics $1982,1647-82$

113 Wettstem PJ Immunodommance in the $\mathrm{T}$ cell response to multiple non- $\mathrm{H} 2$ hustocompatibility antigens II Observation of a hierarchy among dominant antigens Immunogenetics 1986,24 24-31

114 Wettstem PJ, Colombo MP Immunodominance in the $\mathrm{T}$ cell response to multiple non $\mathrm{H} 2$ histocompatibility antrgens IV Partial tissue distribution and mapping of ummunodommant antigens J Immunol 1987,139 2166-2171

115 Korngold R, Wettstem PJ Immumodommance in the graft vs-host disease $T$ cell response to munor histocompatibility antigens J Immunol 1990,145 4079-4088

116 Vagham M, Melanı C, Parmıanı G, D'Eustachio P, Wettstein PJ, Colombo MP Immunodominance in the $T$ cell response to multiple non- $\mathrm{H}-2$ histocompatibility antigens $V$ Chromosomal mapping of the immunodominant cytotoxic $T$ cell target-1 (CTT-1)

Immunogenetics 1993,38 157-160

117 Yin L, Poirier G, Neth O, Hsuan JJ, Totty NF, Stauss HJ Few peptides dominate cytotoxic T lymphocyte responses to single and multuple minor histocompatibility antigens Int Immunol 1993,5 1003-1009

118 Franksson L, Petersson M, Kıessling R, Karre $\mathrm{K}$ Immunization against tumor and mmor histocompatibility antigens by eluted cellular peptudes loaded on antigen processing defective cells

Eur J Immunol 1993,23 2606-2613

119 Wolpert E, Franksson L, Karre K Domman* and cryptic antigens in the MHC class I restricted $\mathrm{T}$ cell response across a compiex minor histocompatıblity barrier analysis and mapping by elution of cellular p'stides Int Immunol 1995,7 919-928

120 Nevala WK, Wettstem PJ The preferential cytolytuc $T$ lymphocyte responsa to ımmunodominant minor hist scompatiblity antıgen peptides

Transplantatron 1996,62 283-291

121 Blazar BR, Roopenian DC, Taylor PA, Christianson GJ, Panokalts1s Mortarı A, Vallera DA Lack of GVHD across classical single minor histocompatıbllty ( $\mathrm{miH}$ ) locus barners in mice Transplantation 1996,61 619-624
122 Perreault C, Jutras J, Roy DC, Filep JG, Brochu $S$ Identification of an ummunodominant mouse minor histocompatibility antigen (MiHA) T cell response to a single dominant MiHA causes graft veısus-host disease J Clin Invest 1996,98 622-628

123 Storb R, et al Methotrexate and cyclosporme compared with cyclosporme alone for piophylaxis of acute graft-versus-host-disease after marrow transplantation for leukemia N Engl J Med 1986,314 829-835

124 Wettstem PJ Immunodommance in the T cell response to multiple non- $\mathrm{H}-2$ histocompatibility antigens III Single histocompatibility antigens dommate the male antugen

J Immunol 1986,137 2073-2079

125 Von Boehmer H, Haas W Distinct Ir genes for helper and kuller cells in the cytotoxic response to $\mathrm{H} Y$ antigen J Exp Med 1979,150 1134-1142

126 Davis AP, Roopenian DC Complexaty at the mouse minor histocompatibility locus $\mathrm{H}-4$ Immunogenetıcs 1990,31 7-12

127 Roopenıan DC, Davis AP, Chrıstianson GJ, Mobraaten LE The functional basis of nunor histocompatibility loci J Immunol 1993,151 4595-4605

128 Zuberı AR, Nguyen HQ, Auman HJ, Taylor BA, Roopenian DC A genetic linkage map of mouse chromosome 2 extending from thrombospondin to parred box gene 1 , including the $\mathrm{H} 3$ minor histocompatibility complex

Genomics 1996,33 75-84

129 Topalıan SL, et al Human CD4+ $T$ cells specifically recognize a shared melanomaassoicated antigen encoded by the tyrosinase gene Proc Natl Acad Sc USA 1994,91 9461-9465

130 Connolly JM The peptide p2Ca is mmuno dommant in allorecognition of $L^{d}$ by $\beta$ chan variable region $\mathrm{V} \beta 8^{+}$but not $\mathrm{V} \beta 8$ strans Proc Natl Acad Scı USA 1994,91 11482-11486

131 Chen W, Khilko S, Fecondo J, Margulres DH, McCluskey J Determmant selectron of major histocompatibility complex class I restricted antigenic peptides is explained by class I peptide affinity and is strongly influenced by nondommant anchor resıdues J Exp Med 1994,180 1471-1483

132 Wettstein PJ, Van Bleek GM, Nathenson SG Differential binding of a inmor histocompatibility antigen peptide to $\mathrm{H}-2$ class I molecules correlates with immune responsiveness

J Inmunol 1993,150 2753-2760

133 Chen Y, et al Naturally processed peptides longer than nune armmo acid residues bind to the class I molecule HIA-A2 1 with high affinity and in different confirmations J Immunol 1994, 152 2874-2881
134 Ruppett J, Sidney J, Celıs E, Kubo R, Grey HM, Sette A Prommant role of secondary anchor residue in peptide binding to HILA A2 1 molecules Cell 1993,74 929-937

135 Cox AL, et al Identufication of a peptide recognized by five melanoma-specific human cytotoxic $T$ cell hnes

Science 1994,264 716-719

136 Krenger A, Ferrara JLM Dysregulation of cytokmes graft-versus-host disease

J Hematother 1996,5 3-14

137 Abhyankar S, Gilhland DG, Ferrara JLM Interleukin 1 is a critical effector molecule during cytokıne dysregulation in graft versus host disease to mmor histocompatibility antigens Transplantation 1993,56 1518-1523

138 Piguet PF, Grau GE, Allet B, Vassallı P Tumor necrosis factor cachetm is an effector of skm and gut in the acute phase of GVHD J Exp Med 1987,166 1280-1289

139 Micomet I, et al GVIDD mortalıty unduced by non-cytolytic CD4+ $T$ cell clones specific for non $\mathrm{H}-2$ antigens J Immunol 1990,145 2123-2131

140 Hirokawa M, et al Lymphokme acitivity production in graft-verus host reactions across mmor histocompatıbility antigen barlers Clin Exp Immunol 1989,66 434-439

141 Dickmson AM, et al Cytokme mvolvement m predicung test for graft versus-host disease in allogeneıc bone marrow transplant recipıents Bone Marrow Transplant 1994, 13 65-70

142 Van Lochem EG, Van der Keur M, Mommaas M, De Gast GC, Goulmy E Expression of cytotoxic $T$ cell defined minor histocompatıbility antugens on human peripheral blood dendritıc colls and skın derıved Langerhans cells Transpl Immunol 1996,4 151-157

143 Macatonia SE, Taylor PM, Knight SC, Askonas BA Primary stimulation by dendritic cells induces antıviral piolferatıve and cytotoxıc $T$ cell responses $m$ vitro J Exp Med 1989,169 1255-1264

144 Mehef CJM Dendritic cells as specialized antigen-presenting cells Res Immunol 1989,140 902-906

145 Penault C, et al Persistence of host Langerhans cells following allogeneic bone marrow transplantation possible relationshup with acute giaft-versus-host disease Bi J Haematol 1984,60 253-260

146 Schlegel PG, et al Prevention of giaft-versushost disease by peptıdes binding to class II major histocompatibility complex molecules Blood 1994,84 2802-2810 
147 Schlegel PG, Aharon R, Vaysburd M, Tran N, McDevitt HO, Chao NJ Inhibition of secondary MLR and prevention of murne graft-versus-host disease across minor histocompatıbility barriers by peptides with high binding affinity for class II MHC molecules FASEB J 1994,8 478(Abstract)

148 Sloan-Lancaster J, Allen PM Altered peptıde hgant-induced partial $T$ cell actrvation molecular mechannsms and role in $\mathrm{T}$ cell bılogy Annu Rev Immunol 1996,14 1-27

149 Klenermann P, Meier UC, Philips RE, McMichael AJ The effects of natural altered peptide ligangs on the whole blood cytotoxic T' lymphocyte response to human immunodeficiency virus

J Immunol 1995,25 1927-1931

150 Snoke $\mathrm{K}$, et al The inhibition of different $T$ cell lines specific for the same antigen with TCR antagonist peptides

J Immunol 1993,151 6815-6821

151 Brochu S, Roy DC, Perreault C Tolerance to host mmor histocompatibility antigens after allogeneic bone marrow transplantation J Immunol 1992,149 3135-3141
152 Brochu S, Baron C, Bélanger R, Perreault C Graft-host tolerance in bone marrow transplant chimeras Absence of graft-versus host disease is associated with unresponsiveness to minor histocompatibility antigens expressed by all tussues

Blood 1994,84 3221-3228

153 Irschick EU, et al Studies on the mechanism of tolerance for graft-versus-host disease in allogeneic bone marrow recipients at the level of cytotoxic $T$ cell precursor frequencies Blood 1992,79 1.622-1628

154 De Bueger M, Bakker A, Goulmy E Acqured tolerance for minor histocompatibility antigens after HLA dentical bone marrow transplantation Int Immunol 1992,4 53-57

155 Davies JD, Leong LYW, Mellor A, Cobbold SP, Waldmann $H \mathrm{~T}$ cell suppression in transplantation tolerance through linked recognition

J Immunol 1996,156 3602-3607

156 Giralt SA, Champlın RE Leukemıa relapse after allogeneic bone marrow transplantation Blood 1994,84 3603-3612

157 Kolb HJ, et al Donor leukocyte transfusions for treatment of recurrent chronic mycologenous leukemia in marrow transplant patients Blood 1990,76 2462-2465

158 Hertenstem $B$, et al Interferon $\alpha$ and donor buffycoat transfusions for treatment of relapsed chronic myelord leukema after allogeneic bone marrow transplantation Transplantation 1993,56 1114-1118
159 Slavm S, Naparstek E, Nagler A, Ackerstem A, Kapelushnik J, Or R Allogeneic cell therapy for relapsed leukemıa after bone marrow transplantation with donor peripheral blood lymphocytes

Exp Hematol 1995,23 1553-1562

160 Antın JH Graft-versus-leukemıa No longer an eprphenomenon Blood 1993,82 2272-2277

$161 \mathrm{Kolb} \mathrm{HJ}$, et al Graft-versus-leukemıa effect of donor lymphocyte transfusions in marrow grafted patients Blood 1995,86 2041-2050

162 Rooney CM, et al Use of gene-modified vurus-specific $T$ lymphocytes to control of Epstein Barr virus related lymphoproluferation Lancet 1995,345 9-13

163 Riddell SR, Greenberg PD Principles for adoptrve $T$ cell therapy of human viral diseases

Annu Rev Immunol 1995,13 545-586

164 Van der Harst D, et al Recognition of minor histocompatibility antigens on lymphocytıc and myelord leukemic cells by cytotoxic $T$ cell clones

Blood 1994,83 1060-1066

165 Falkenburg JHF, et al Growth inhibition of clonogenic leukemic precursor cells by histocompatibility antigen-specific cytotoxic T lymphocytes

J Exp Med 1991,174 27-33 